\title{
Effects of Plant Spacing and Time of Harvesting on Yield and Tuber Size Distribution of Potato (Solanum tuberosum L) Variety Southeast Ethiopia
}

\author{
Demis Fikre Limeneh ${ }^{1, ~ *}$, Fekadu Gebretensay Mengistu², Gizaw Wegayehu Tilahun ${ }^{1}$, \\ Dasta Tsagaye Galalcha $^{1}$, Awoke Ali Zeleke ${ }^{1}$, Nimona Fufa Hundie ${ }^{1}$ \\ ${ }^{1}$ Kulumsa Agricultural Research Center, Ethiopian Institute of Agricultural Research, Assela, Ethiopian \\ ${ }^{2}$ Debre Zeit Agricultural Research Center, Ethiopian Institute of Agricultural Research, Debre Zeit, Ethiopian
}

Email address:

fikredemis@gmail.com (D.F. Limeneh)

${ }^{*}$ Corresponding author

\section{To cite this article:}

Demis Fikre Limeneh, Fekadu Gebretensay Mengistu, Gizaw Wegayehu Tilahun, Dasta Tsagaye Galalcha, Awoke Ali Zeleke, Nimona Fufa Hundie. Effects of Plant Spacing and Time of Harvesting on Yield and Tuber Size Distribution of Potato (Solanum tuberosum L) Variety Southeast Ethiopia. American Journal of Bioscience and Bioengineering. Vol. 9, No. 1, 2021, pp. 1-7. doi: 10.11648/j.bio.20210901.11

Received: December 19, 2020; Accepted: January 6, 2021; Published: February 9, 2021

\begin{abstract}
Potato is one of the most important crops in the farming system of Bekoji and Kofele in the cool highlands of Arsi where potato is usually grown biennially during the main and 'bulg' seasons. 'Belete' has been the dominant potato variety in these areas for the last ten years now and farmers prefer to grow this variety for its high productivity and resistance to late blight disease. Nevertheless, farmers have complaints on its big sized tubers, considered as unmarketable, which costs them more seed to cover a given area of land and less suitable for cooking. Besides, farmers often use random population density and time of harvesting, which also contribute to this problem. The present study was therefore intended to manage the tubers' size distribution of this variety without negatively affecting the yield of the crop through modifying plant spacing and time of harvesting from previously recommended practices. Twelve combinations of four plant spacing and three time of harvesting were studied on variety 'Belete' at Bekoji and Kofele in the main seasons of 2018 and 2019. The experiment was laid out in a completely randomized block design with $4 \times 3$ factorial arrangement in three replications. The analysis of variance revealed that the interaction effect of spacing and time of harvesting significantly $(\mathrm{p}<0.001)$ affected the marketable tuber yields. The narrow spacing $(60 \mathrm{~cm} \times 20 \mathrm{~cm})$ or high population treatment $(83,333$ plants $/$ ha) with 120 days after planting resulted in the highest marketable and total tuber yield compared to the rest. While the least yields were recorded from the wider spacing of $75 \mathrm{~cm} \times 30 \mathrm{~cm}(44,444$ plants/ha) and early harvesting (90 days). The spacing $60 \mathrm{~cm} \times 20 \mathrm{~cm}$ did $17.2 \%$ increment in marketable yield over the previously recommended spacing of potato $(75 \mathrm{~cm} \times 30 \mathrm{~cm}, 44,444$ plants $/$ ha). From this study, therefore, it can be recommended for Belete that the narrow spacing of $60 \mathrm{~cm} \times 20 \mathrm{~cm}$ and harvesting at 120 days after planting could be the optimum spacing and time of harvesting to produce marketable tubers.
\end{abstract}

Keywords: Days After Planting, Tuber Size Distribution, Marketable Yield, Unmarketable Yield

\section{Introduction}

Potato (Solanum tuberosum L.) is one of the most important agricultural crops in the world. In volume of production, it ranks fourth in the world after maize, rice and wheat, with an estimated production area of 18.9 million hectares [1]. Potato is regarded as a high-potential food security crop because of its ability to provide a high yield of high-quality product per unit input with a shorter crop cycle (mostly $<120$ days) than the major cereal crops [2].

The average composition of the potato tuber is about $80 \%$ water, $2 \%$ protein and $18 \%$ starch. As a food it is one of the cheapest and easily available sources of carbohydrates and protein and contains appreciable amount of vitamin $\mathrm{B}$ and $\mathrm{C}$ as well as some minerals. Moreover, protein of potato is of high biological value $[3,4]$.

Global production of potatoes was 388 million tons, led by China with $64 \%$ of the world total. China is now the biggest 
potato producer, and almost a third of all potatoes are harvested in China and India [5]. Secondary producers were Algeria and Nigeria [5] while the current average potato productivity in Africa has been reported to be about $13.22 \mathrm{t}$ $\mathrm{ha}^{-1}$ which is well below the maximum productivity of 20.11 $\mathrm{t} \mathrm{ha}^{-1}$ [5]. The average yield of potato in Ethiopia ranges only between 8 to $10 \mathrm{t} \mathrm{ha}^{-1}$, which is much lower than the yields obtained in the Sudan $\left(17 \mathrm{t} \mathrm{ha}^{-1}\right)$ and Egypt (26 t ha $\left.{ }^{-1}\right)$ [6]. Although, the edaphic and climatic conditions are suitable for production of high quality potato in Ethiopia, the national average production is as low as $8 \mathrm{tha}^{-1}$ [7].

In Oromia Region potato production coverage was estimated about $38,925.67$ ha from which $484,831.16$ tons of potato was produced with an average yield of $12.46 \mathrm{tha}^{-1}[8]$. In Ethiopia, potato is a high potential food security crop due to its high yield potential per hectare and nutritious tubers. Potato production in Ethiopia is possible on about $70 \%$ of the arable land [9]. Potato is a leading vegetable crop in Ethiopia and smallholder farmers cultivate about 50,000 ha each season [10]. Moreover, in Ethiopia potato production serves as a means to overcome food shortage periods 'hungry months', since it matures before the harvest of other food crops such as cereals [11].

The yield of potato is influenced by a number of factors, which include nitrogen, cultivar, seed piece spacing, climatic conditions and geographic location [12]. Plant spacing and time of harvesting are amongst the factors which could affect the yield as well as the size of tubers in potato. As plant density increases (closer spacing) there is a marked decrease in plant size and yield per plant, while at lower plant density (wider spacing), the reverse could happen. This effect is due to inter-plant competition for water, light and nutrient. It is therefore, essential to understand how individual plants interact with each other and the environment and to possibly come up with the ideal crop density level to optimize yields and tuber sizes.

In Ethiopia it is a common practice to use a spacing of $75 \mathrm{~cm}$ (inter row) $\mathrm{x} 30 \mathrm{~cm}$ (intra row) and $/$ or $60 \mathrm{~cm} \times 20 \mathrm{~cm}$ to produce potato for table and seed purpose respectively for all varieties. However, using this spacing, the commonly grown variety 'Belete' produces large tubers, which are not usually acceptable by farmers, either for seed or table purposes. Besides, variations in tuber size distribution among varieties influence the seed rate to be used for a given area of land. Some varieties such as 'Belete' produces large tubers among others potato varieties and consequently, a higher seed rate is required to cover a hectare of land and also growers have complaints that big sized tubers could take longer time for cooking. In addition to plant spacing, time of harvesting in potato also have influence on tuber sizes as tubers develop in different physiological time starting from tuber initiation to bulking stage. Most farmers harvest potatoes when its vine (haulm) is dead naturally, which could result in bigger sized tubers particularly for 'Belete' variety. Therefore, the present study was carried out to study the tubers' size distribution of variety 'Belete' in response to different plant spacing and times of harvesting.

\section{Materials and Methods}

\subsection{Description of the Study Area}

The experiment was conducted at Bekoji and Kofele, Southeastern Ethiopia during the main growing season in 2018 and 2019. Bekoji and Kofele are the two major potato growing areas in Arsi zone of Oromia region which are about $52 \mathrm{~km}$ apart and 227 and $250 \mathrm{~km}$ from Addis Ababa respectively. The study areas are located at an altitude of 2800 and 2650 meter above sea level respectively. The maximum and minimum temperature was 20.48 and $2.63{ }^{\circ} \mathrm{C}$; 20.48 and $3.34^{\circ} \mathrm{C}$ respectively. The study areas have acidic and loam soils and the agro- climatic condition of the areas is wet with 956.6 and $950.6 \mathrm{~mm}$ mean annual rain fall and both have a uni- modal rainfall pattern with extended rainy season from March to September. However, the peak rainy season is from June to August.

Experimental materials, design and procedure

The study was conducted on the improved variety 'Belete', one of the dominant potato varieties in the production system in Ethiopia, originally released from Holeta Agricultural Research Center in 2009 [13]. Twelve treatment combinations of four plant spacing $(75 \mathrm{~cm} \times 30 \mathrm{~cm}$, $75 \mathrm{~cm} \times 20 \mathrm{~cm}, 60 \mathrm{~cm} \times 30 \mathrm{~cm}$ and $60 \mathrm{~cm} \times 20 \mathrm{~cm})$ and three harvesting time $(90,105$ and 120 days after planting) were laid out in a $4 \times 3$ factorial arrangement using Randomized Complete Block Design (RCBD) in three replications. Medium sized seed tubers $(35-55 \mathrm{~mm})$ were planted per plot $\left(9 \mathrm{~m}^{2}\right)$ for each treatment combination based on the spacing treatments mentioned above. The required agronomic practices such as cultivation (weeding), ridging, fertilization, pesticide application, etc. were applied to all experimental units. Fertilizers were applied at the rate of $242 \mathrm{~kg} \mathrm{ha}^{-1}$ NPS and $150 \mathrm{~kg} \mathrm{ha}^{-1}$ Urea, in which Urea is applied in split application, half dose at full emergence and the rest half after 45 days depending on the fertility level of the soil. Late blight disease (Phytophtora infestans) occurred on the experimental fields was managed with Redomil and Mancozeb.

\subsection{Data Collected}

The data was collected on tuber yield and yield related traits such as number of main stem per hill, $50 \%$ stem height, marketable tubers yield $\mathrm{t} \mathrm{ha}^{-1}$, Small size tuber yield $\mathrm{t} \mathrm{ha}{ }^{-1}$, unmarketable tubers yield $\mathrm{t} \mathrm{ha}^{-1}$ and total tubers yield $\mathrm{t} \mathrm{ha}^{-1}$ and specific gravity.

\subsection{Data Analysis}

The collected data were subjected to Analysis of Variance (ANOVA) using statistical analysis Software (SAS version 9.2, 2008). The mean separation was done using (LSD) test at $5 \%$ probability level.

\section{Results and Discussion}

The combined analysis of variance revealed that, stem 
number, stem height, marketable yield, small size tubers, unmarketable yield and total tuber yield were all significantly $(P<0.05)$ influenced by the main effects of time of harvesting. However, spacing only affected potato marketable and total yields per hectare. While the interaction effect of the two factors brought about highly significant $(P<0.01)$ effects on total marketable yields per hectare.

Table 1. Main effect of spacing and harvesting time on stem number, stem height, marketable yield, small size tubers, unmarketable yield and total tuber yield across locations and years grown at Bekoji and Kofele, South East Ethiopia in 2018 and 2019.

\begin{tabular}{|c|c|c|c|c|c|c|c|}
\hline Spacing & $\begin{array}{l}\text { Stem number at } \\
50 \% \text { flowering }\end{array}$ & $\begin{array}{l}\text { Stem height at } \\
\text { flowering }\end{array}$ & $\begin{array}{l}\text { Marketable yield } \\
\mathrm{t} \mathrm{ha}^{-1}\end{array}$ & $\begin{array}{l}\text { Small size tuber } \\
\text { yield } \mathrm{t} \mathrm{ha}^{-1}\end{array}$ & $\begin{array}{l}\text { Unmarketable } \\
\text { yield } \mathrm{t} \mathrm{ha}^{-1}\end{array}$ & $\begin{array}{l}\text { Total yield } t \\
\mathrm{ha}^{-1}\end{array}$ & $\begin{array}{l}\text { Specific } \\
\text { gravity }\end{array}$ \\
\hline $75 \mathrm{~cm}^{*} 30 \mathrm{~cm}$ & 3.57 & 81.67 & $44.23 b$ & 4.14 & 9.07 & $53.31 \mathrm{~b}$ & 1.1 \\
\hline $75 \mathrm{~cm}^{*} 20 \mathrm{~cm}$ & 3.72 & 84.06 & $46.39 b$ & 4.42 & 10.62 & $57.07 \mathrm{~b}$ & 1.1 \\
\hline $60 \mathrm{~cm}^{*} 30 \mathrm{~cm}$ & 3.38 & 81.27 & $45.60 \mathrm{~b}$ & 4.32 & 10.06 & $55.94 b$ & 1.1 \\
\hline $60 \mathrm{~cm}^{*} 20 \mathrm{~cm}$ & 3.53 & 81.71 & $53.43 a$ & 4.42 & 10.53 & $63.97 \mathrm{a}$ & 1.1 \\
\hline $\operatorname{LSD}(5 \%)$ & NS & NS & 41.99 & NS & NS & 50.49 & NS \\
\hline \multicolumn{8}{|c|}{ Harvesting time } \\
\hline 90 & $3.44 \mathrm{~b}$ & $79.48 b$ & $42.36 b$ & $5.08 \mathrm{a}$ & $12.97 \mathrm{a}$ & $55.33 b$ & 1.1 \\
\hline 105 & $3.94 \mathrm{a}$ & $82.10 \mathrm{ab}$ & $49.03 a$ & $4.20 \mathrm{ab}$ & $7.23 \mathrm{c}$ & $56.26 \mathrm{~b}$ & 1.1 \\
\hline 120 & $3.28 \mathrm{~b}$ & $84.95 \mathrm{a}$ & $50.84 a$ & $3.69 b$ & $10.02 b$ & $61.07 \mathrm{a}$ & 1.1 \\
\hline $\begin{array}{l}\text { LSD }(5 \%) \\
\text { locations }\end{array}$ & 0.38 & 3.45 & 36.37 & 8.72 & 17.17 & 43.73 & NS \\
\hline Bekoji & $3.93 \mathrm{a}$ & $79.57 b$ & $45.71 b$ & 4.51 & 10.19 & 59.21 & 1.10 \\
\hline Kofele & $3.17 \mathrm{~b}$ & $84.78 \mathrm{a}$ & $49.12 \mathrm{a}$ & 4.14 & 9.95 & 55.91 & 1.09 \\
\hline $\operatorname{LSD}(5 \%)$ & 0.31 & 2.82 & 29.69 & NS & NS & NS & NS \\
\hline CV $(\%)$ & 26.62 & 10.41 & 18.97 & 49.91 & 42.17 & 18.79 & 1.12 \\
\hline
\end{tabular}

LSD0.05 = least significant difference at $5 \%, \mathrm{CV}(\%)=$ Coefficient of variation. Means in the same column followed by the same letter (s) are not significantly different.

\subsection{Stem Number at 50\% Flowering}

The analysis of variance revealed that stem number of potato were significant $(P<0.05)$ due to main effect of time of harvesting, but statistically non-significant with spacing $(P>0.05)$.

Numerically the highest (3.94) stem number was recorded from 105 days after planting, while lowest (3.28) was obtained from time of harvesting 120 days after planting, but spacing was not significantly $(P>0.05)$ affected stem number per hill. Stem numbers were reduced at high plant density level and increased significantly at lower densities. This might be due to population density and competition effect for recourse like sun light, nutrient and water. Some studies, for example in which the relation between plant spacing and growth were examined, the results showed an increase in plant spacing to be accompanied by an increased stem length. The increased branching at the wider spacing did not compensate for fewer plants $/ \mathrm{m}^{2}$. They attributed increased branching at wider spacing to the availability of more space at lower plant densities. More space meant that plants were able to exploit the available nutrients in the soil and the photosynthetic active radiation for growth than plants at close spacing [14]. However, location has very highly significantly affected $(\mathrm{P}<0.001)$ stem number per hill. The highest stem number was recorded at Bekoji, while the lowest was obtained at Kofele (Table 1). This could be due to environmental factors, such as soil variability, altitudes etc. At Bekoji, the soil is nitosol (red) or more acidic and has high rain fall and nutrient availability. At Kofele the soil was clay loam soil, water logged areas and high nutrient availability.

\subsection{Stem Height at 50\% Flowering}

The combined analysis of variance revealed that stem height of potato was significantly $(P<0.05)$ affected by main effect of time of harvesting but not statistically affected by both spacing and their interaction (Table 1).

Numerically the highest $(84.95 \mathrm{~cm})$ stem height was recorded at 120 days after planting. The shortest $(79.48 \mathrm{~cm})$ stem height was obtained from 90 days after planting. But spacing was not significantly $(P>0.05)$ affected stem height. This contradicting result could be due to soil variability, planting season, moisture levels, and variety response to location, light energy, biotic factors or other environmental factors affecting the influence of plant spacing. On the other hand location has very highly significantly affected $(P<0.01)$ stem height. Numerically the highest $(84.78 \mathrm{~cm})$ stem height was recorded from Kofele location; while the shortest $(79.57 \mathrm{~cm})$ was obtained at Bekoji (Table 1). This could be due to differences in environmental factors, soil variability, altitudes and amount of rainfall between the locations. At Bekoji the soil was nito soil (red) or more acidic and high rain fall and nutrient availability.

\subsection{Marketable Tuber Yield tha $\mathrm{ha}^{-1}$}

The combined analysis of variance revealed that, marketable tuber yield of potato were significant $(P<0.05)$ due to main effect of both time of harvesting and spacing (Table 1$)$, and very highly significant $(P<0.001)$ with their interaction on marketable tuber yield $\mathrm{t} \mathrm{ha}^{-1}$.

The highest (50.84 $\mathrm{t} \mathrm{ha}^{-1}$ ) marketable tuber yield was obtained from 120 days after planting, while lowest $(42.361 \mathrm{t}$ $\mathrm{ha}^{-1}$ ) marketable tuber yield was recorded from 90 days after 
planting. This might be due to the fact that at full maturity/physiological maturity, small size tubers grown in to medium size tubers through increased photo assimilation, metabolic processes including cell division, cell expansion, respiration and photosynthesis. Time of harvesting in potato have influence on tuber sizes as tubers develop in different physiological time starting from tuber initiation to bulking stage. However, an experiment conducted at Bekoji in 2017 showed that, there was a tendency that marketable tuber yield was declining with delayed harvesting. This could be for the very reason that potato tubers could increase bulking and increased large sized tubers towards late harvesting (Figure 1). This was also in line with the decreasing numbers of small sized tubers towards late maturity (Figure 2).

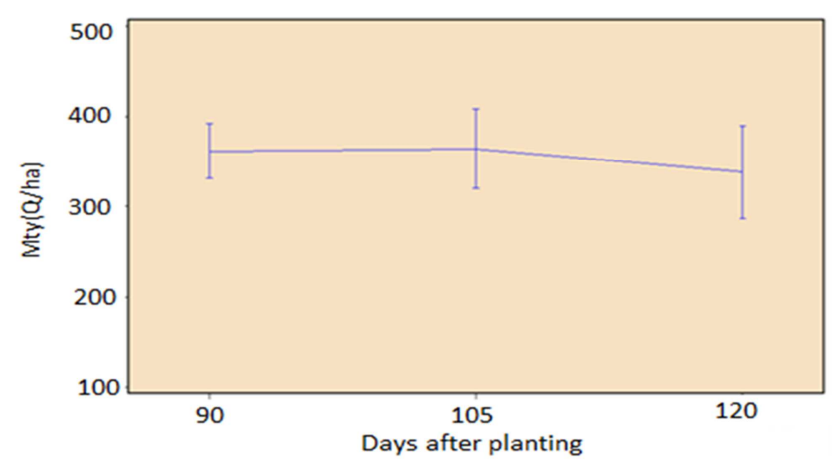

Figure 1. Response of marketable tuber yield to time of harvesting at Bekoji, 2017

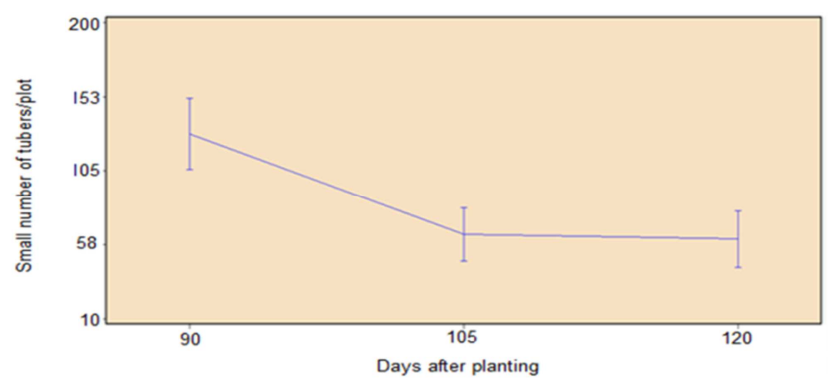

Figure 2. Response of small number of tubers (unmarketable) to time of harvesting at Bekoji, 2017.

Similarly the marketable tuber yield $\mathrm{t} \mathrm{ha}^{-1}$ was affected by spacing. Numerically the highest (53.43) marketable tuber yield $\mathrm{t} \mathrm{ha}{ }^{-1}$ was obtained at the narrow spacing of $60 \mathrm{~cm} \times 20 \mathrm{~cm}$, while lowest value (44.28) marketable tuber yield was recorded at the wider spacing of $75 \mathrm{~cm} \times 30 \mathrm{~cm}$. The highest marketable yield recorded at closer spacing is attributed to more tubers produced at the higher plant population per hectare. The result is analogous with the findings of [15]; reported that increasing plant density increases the tuber yield per plant. The findings of [16] also reported that the combination of inter and intra spacing had significant effect on number of marketable yield. In a related study [17] reported that wider spacing produced few tubers as it gave rise to few stems that could lead to high number and possibly tubers, but closer spacing improved quality and saleable yield. The present result is contradicting with [18] highest marketable yield was obtained at the wider intra row spacing of $30 \mathrm{~cm}$ whereas the lowest was obtained at closer spacing of $10 \mathrm{~cm}$. Our results are in line with what was found by [19] in that increasing the planting density from 4.44 to 6.67 plants $\mathrm{m}^{-2}$ significantly increased total and marketable tuber yield by 5.21 and $4.67 \mathrm{tha}^{-1}$. Our result showed that increasing plant population from $75 \mathrm{~cm} \times 30 \mathrm{~cm}(4.4$ plants $/ \mathrm{m} 2)$ to $60 \mathrm{~cm} \times 20 \mathrm{~cm}(8.33$ plants $/ \mathrm{m} 2)$ increased marketable tuber yield from 44.23 to $53.43 \mathrm{t} / \mathrm{ha}$ ). As mentioned above on the effect of time of harvesting on marketable yields, the study in 2017 at Bekoji explained that increasing plant population significantly increased marketable tuber yields to until an optimum point where marketable tuber yield started to decline due to increased number of small number of tubers (Figures 3 and 4).

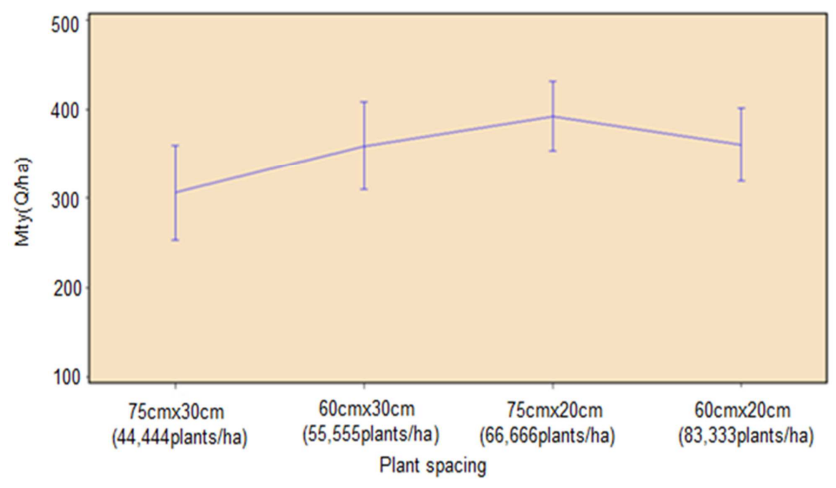

Figure 3. Response of marketable tuber yield to plant spacing (plant population) at Bekoji, 2017.

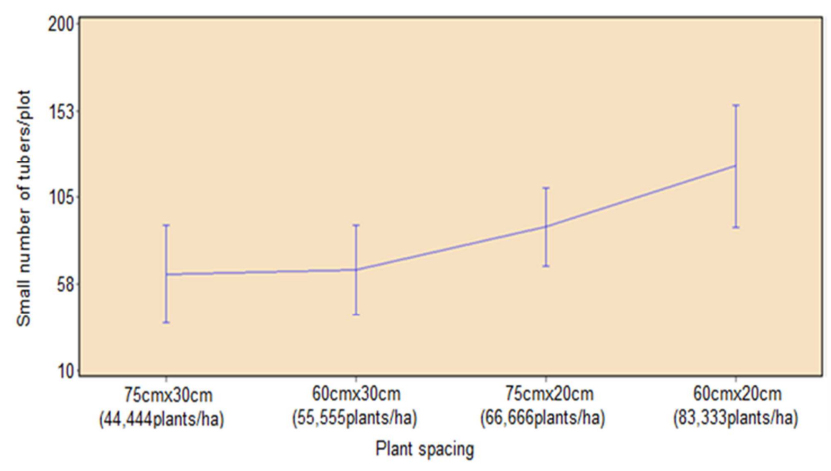

Figure 4. Response of small number of tubers to plant spacing (plant population) at Bekoji, 2017.

The combinations of spacing $(60 \mathrm{~cm} \times 20 \mathrm{~cm})$ and 120 days after planting resulted in better marketable potato yield per hectare. The lowest mean marketable yield was recorded from spacing of $60 \times 30 \mathrm{~cm}$ and 90 days after planting treatments. The combinations of the spacing of $60 \mathrm{~cm} \times 20 \mathrm{~cm}$ and 120 days after planting brought about $17.2 \%$ increments in marketable yield per hectare over the of spacing $(70 \times 30 \mathrm{~cm})$ and early harvesting such as 90 days after planting (Table 2). The increased yield at higher densities may be attributed to the higher ground covered with green leaves earlier (earlier in the season, light is intercepted and used for assimilation), fewer lateral branches being formed and tuber growth starting earlier. To produce smaller tubers, higher plant densities are needed than for the production of 
big tubers. Consistent with this suggestion, increased plant population density increased yield due to more tubers being harvested per unit area of land [20]. However, decreases in total yields as a result of wider spacing were compensated for in part by increased production of large-sized tubers and decreased production of small-sized tuber. This is apparently a result of reduced interplant competition, which leads to increased production of total tuber numbers per plant and increased average tuber size with wider seed piece spacing [21]. This result is analogous with [18] highest marketable yield was obtained at the wider intra row spacing of $20 \mathrm{~cm}$ whereas the lowest was obtained at closer spacing of $10 \mathrm{~cm}$. According to [19] increasing the planting density from 4.44 to 6.67 plants $\mathrm{m}^{-2}$ significantly increased total and marketable tuber yield by 5.21 and $4.67 \mathrm{tha}^{-1}$.

On the other hand location has very highly significantly affected $(P<0.001)$ marketable yield. Numerically the highest $\left(49.12 \mathrm{t} \mathrm{ha}^{-1}\right)$ marketable tuber yield was obtained from Kofele location; while the lowest $\left(45.71 \mathrm{t} \mathrm{ha}^{-1}\right)$ was recorded from Bekoji location (Table 1 and Figure 1). This may be due to differences in environment and edaphic factors such as amount of rainfall and soil type.

Table 2. The interaction effect of days after harvesting and spacing on marketable yields grown at Bekoji and Kofele in 2018 and 2019.

\begin{tabular}{lll}
\hline DAH & Spacing & Marketable yield t $\mathbf{h a}^{-1}$ \\
\hline & $75 \mathrm{~cm} \times 30 \mathrm{~cm}$ & $41.94^{\mathrm{de}}$ \\
90 & $75 \mathrm{~cm} \times 20 \mathrm{~cm}$ & $41.94^{\mathrm{de}}$ \\
& $60 \mathrm{~cm} \times 30 \mathrm{~cm}$ & $38.38^{\mathrm{e}}$ \\
& $60 \mathrm{~cm} \times 20 \mathrm{~cm}$ & $47.17 \mathrm{~b}^{\mathrm{cd}}$ \\
105 & $75 \mathrm{~cm} \times 30 \mathrm{~cm}$ & $44.86^{\mathrm{cde}}$ \\
& $75 \mathrm{~cm} \times 20 \mathrm{~cm}$ & $47.29^{\mathrm{bdd}}$ \\
& $60 \mathrm{~cm} \times 30 \mathrm{~cm}$ & $50.18^{\mathrm{bc}}$ \\
& $60 \mathrm{~cm} \times 20 \mathrm{~cm}$ & $53.81^{\mathrm{ab}}$ \\
120 & $75 \mathrm{~cm} \times 30 \mathrm{~cm}$ & $45.88^{\mathrm{cd}}$ \\
& $75 \mathrm{~cm} \times 20 \mathrm{~cm}$ & $49.92^{\mathrm{bc}}$ \\
& $60 \mathrm{~cm} \times 30 \mathrm{~cm}$ & $48.25^{\mathrm{bcd}}$ \\
Mean & $60 \mathrm{~cm} \times 20 \mathrm{~cm}$ & $59.31^{\mathrm{a}}$ \\
LSD $(0.05)$ & & 47.42 \\
CV $(\%)$ & & 69.05 \\
\hline
\end{tabular}

LSD0.05 = least significant difference at 5\%, CV $(\%)=$ Coefficient of variation, $\mathrm{DAH}=$ days after harvesting. Means in the same column followed by the same letter (s) are not significantly different.

\subsection{Small Size Tuber Yield tha $\mathrm{ha}^{-1}$}

The combined analysis of variance revealed that small size tuber yield of potato were significant $(P<0.05)$ due to the main effect of time of harvesting, but spacing, locations and their interaction did not show significant difference on small size tuber yield $\mathrm{t} \mathrm{ha}^{-1}$ (Table 1).

Numerically the highest $\left(5.08 \mathrm{tha}^{-1)}\right.$ small size tubers were obtained from 90 days after planting, while the lowest $(3.69 \mathrm{t}$ $\mathrm{ha}^{-1}$ ) was recorded from 120 days after planting. This might due to early harvesting or discriminate harvesting of potato before full matured/physiological maturity. Under sized potato tuber yield increases, unmarketable yields also increased. Before full maturity harvesting of potato disturbed more photosynthesis in a general increment of most metabolic processes including cell division, cell expansion, and respiration activities were reduced. For this reason small size tuber or unmarketable number and yields also increased. This result was also supported by an experiment conducted at Bekoji in 2017 showing a clear variation in amount of small sized tubers between early and late harvesting (Figure 2).

Spacing and location were did not show significant difference on small size tubers. This might be due to population density and competition effect for recourse like sun light, nutrient and water. This contradicting result could be due to soil variability, planting season, moisture levels, and variety response to location, light energy, biotic factors or other environmental factors affecting the influence of plant spacing. However, the same experiment conducted in 2017 at Bekoji showed that like time of harvesting, spacing also affected the amount of small sized tubers (Figure 4). Increasing plant population increased small sized tubers per unit area. This was due to the reason that plants compete for different resources at higher population than at lower population resulting more number of small sized tubers per plant which could increase unmarketable tuber yields.

\subsection{Unmarketable Yield $\mathrm{t} \mathrm{ha}^{-1}$}

The combined analysis of variance revealed that unmarketable tuber yield of potato were highly significant $(P<0.05)$ due to the main effect of time of harvesting, but spacing, locations and their interactions did not show significant difference on unmarketable tuber yields $\mathrm{t} \mathrm{ha}^{-1}$ (Table 1)

Numerically the highest $\left(12.97 \mathrm{tha}^{-1)}\right.$ unmarketable tuber yield was obtained from 90 days after planting, while the lowest $\left(7.23 \mathrm{t} \mathrm{ha}^{-1}\right)$ was recorded from 105 days after planting. This might due to early harvesting or discriminate harvesting of potato before full matured/physiological maturity and very small size tubers increases during early harvesting of potato (Table 1, Figure 2). At late harvesting or over maturity of potato, the very large tubers increases and unmarketable potato yields increased. To increase the marketability of potato yields, it is important to harvest at optimum harvesting time like 105 days after planting (Figure 1). Early harvesting (90 days) however increased unmarketability of potato tubers due to increased number of small sized tubers while late harvesting also did the same due to increased number of large tuber numbers, which are also unmarketable as far as Belete variety is concerned. Spacing and location were did not show significant difference on unmarketable tuber yields (Table 1) This contradicting result could be due to soil variability, planting season, moisture levels, and variety response to location, light energy, biotic factors or other environmental factors affecting the influence of different plant spacing. Nevertheless, results of similar experiment at Bekoji in 2017 showed that plant spacing affected the unmarketability of Belete tubers by increasing the number of small tubers per unit area (Figure 4). Generally, plants grown at closer spacing produced high unmarketable tuber yield than plants grown at wider plant spacing. Increasing plant density also increased the yield of 
unmarketable tuber yield. Closer plant spacing increased competition of plants for growth factors due to high number plant per unit area than wider plant spacing which led to producing high number of under size tubers which was high unmarketable tuber yield [22].

\subsection{Total Tuber Yield $\mathrm{ha}^{-1}$}

The main effect of harvesting time and Spacing showed a very highly significant $(P<0.001)$ differences on total tuber yield per hectare (Table 1). The highest $\left(61.07 \mathrm{t} \mathrm{ha}^{-1}\right)$ total tuber yield was obtained from 120 days after planting, while lowest value $\left(55.33 \mathrm{t} \mathrm{ha}^{-1}\right)$ was recorded from 90 days after planting. This might be due to the fact that at full maturity/physiological maturity, small size tubers get bulked to medium/ large sized tubers which could increase the total tuber yield. On the other hand the low tuber yields at early harvesting time could be attributed to more number of under sized and immature tubers.

Similarly the highest total tuber yield $\left(63.97 \mathrm{t} \mathrm{ha}^{-1}\right)$ was obtained from the narrow spaced population $(60 \mathrm{~cm} \times 20 \mathrm{~cm})$ whereas the lowest $\left(53.30 \mathrm{t} \mathrm{ha}^{-1}\right)$ was recorded at the wider spaced population $(75 \mathrm{~cm} \times 30 \mathrm{~cm})$ in which yield increased with increased plant population (Table 1). In other words, it was clearly evident from the results that the total tuber yield $\mathrm{ha}^{-1}$ was increased with decreasing plant spacing. These results are completely in agreement with [19] in that, increasing the planting density from 4.44 to 6.67 plants $\mathrm{m}^{-2}$ significantly increased total and marketable tuber yield by 5.21 and $4.67 \mathrm{t} \mathrm{ha}^{-1}$.

\subsection{Correlation of Agronomic, Yield and Yield Components of Potato}

The correlation values explain the apparent association of the agronomic and yield parameters with each other and clearly indicated the magnitude and directions of the association and relationships. Marketable yield of potato was positively and highly significant correlated with stem number and stem height at flowering $\left(\mathrm{r}=0.194^{*}\right)$ and $\left(\mathrm{r}=0.409^{* *}\right)$ respectively. This similarly implied that the increment of stem number and height per plant caused for the increment of marketable yield of potato. Total yield of potato per hectares was positively and highly significant correlation was observed stem number per plant $\left(\mathrm{r}=0.207^{* *}\right)$, stem height $(\mathrm{r}$ $\left.=0.419^{* *}\right)$, Marketable yield $\left(\mathrm{r}=0.905^{* *}\right)$, small size tuber $\left(\mathrm{r}=0.336^{* *}\right)$, and total unmarketable yield per hectare $(\mathrm{r}=$ $0.531 * *)$ (Table 3 ).

Table 3. Pearson Correlation among agronomic and yield components of potato crops across locations and years grown at Bekoji and Kofele, South East Ethiopia in 2018 and 2019.

\begin{tabular}{lllllll}
\hline & SNF & SHF & MTY & SSTY & TUMTY & TY \\
\hline SNF & 1 & & & & & \\
SHF & 0.00980 & 1 & & & & \\
MTY & $0.194^{*}$ & $0.409 * *$ & 1 & 1 & & \\
SSTY & $0.294^{* *}$ & 0.078 & $0.189^{*}$ & $0.408^{* *}$ & 1 & \\
TUMTY & 0.095 & $0.164^{*}$ & 0.120 & $0.336^{* *}$ & $0.531^{* *}$ & \\
TY & $0.207^{*}$ & $0.419 * *$ & $0.905^{* *}$ & $0.239^{* *}$ & $0.359^{* *}$ & \\
SPG & 0.099 & 0.109 & 0.077 & $0.219 * *$ & 1 \\
\hline
\end{tabular}

* \& ** Significant at 5\% and $1 \%$ probability levels, respectively. The decimal numbers without any asterics are non-significant $(P>0.05)$, SNF-Stem number at flowering, SHF=Stem height at flowering, MTY=Marketable yield, SSTY=Small size tuber yield, TUMTY= Total unmarketable yield, TY= Total yield, SPG= Specific gravity.

\section{Conclusion and Recommendations}

In conclusion, the plant spacing of $60 \mathrm{~cm} \times 20 \mathrm{~cm}$ (83,333plants/ha) and harvesting 120 days after planting resulted in the production of the highest marketable and total tuber yields on Belete variety than any other treatments studied. The spacing $60 \mathrm{~cm} \times 20 \mathrm{~cm}\left(83,333\right.$ plants ha $\left.{ }^{-1}\right)$ brought about $17.2 \%$ increments in marketable yield per hectare over the generally recommended spacing of potato $(75 \mathrm{~cm} \times 30 \mathrm{~cm}$, 44,444plants/ha). From this study, therefore, it can be recommended for Belete that the narrow spacing of $60 \mathrm{~cm} \times 20 \mathrm{~cm}$ and harvesting 120 days after planting could be the optimum spacing and time of harvesting to produce marketable tubers.

\section{Acknowledgements}

The authors acknowledge Ethiopian Institute of Agricultural Research (EIAR), Kulumsa Agricultural Research Center (KARC) for financial support and facilitation. The authors are also grateful for researchers and technicians of potato research program at Kulumsa Agricultural Research Centers and Bekoji and Kofele sub sites for their contribution for the successful accomplishment of this study.

\section{References}

[1] Naz F, Ali A, Iqbal Z, Akhtar N, Asghar S, and Ahmad B. 2011. Effect of different levels of NPK fertilizers on the proximate composition of Potato at Abbottabad. Sarhad Journal Agricultural Science. 27 (3): 353-356.

[2] Adane, H., Meuwissen, M. P. M., Tesfaye, A., Lommen, W. J. M., Lanssink, A. O., Tsegaye, A., Struik, P. C. 2010. Analysis of seed potato systems in Ethiopia. Journal of American Potato Research 87: 537-552.

[3] Woolfe, J. A. 1987. The potato in the human diet. Cambridge University press, Cambridge, 231.

[4] Gandapur, A. K. 1995. Evaluation of potato varieties in Hazara. MSc.(Hons) Thesis, department of plant breeding and genetics, NWFP Agricultural University Peshawar. 
[5] FAO, Food and Agriculture Organization of the United Nations, FAOSTAT database. 2019. http: //faostat.fao.org/site/567/ default.aspx\#ancor, accessed 25 Dec, 2019

[6] Haverkort, A. J., Koesveld, M. J., van, Schepers, H. T. A. M., Wijinands, J. H. M., Wustman, R., Zhang, X. Y. 2012. Potato prospects for Ethiopia on the road to value addition. Lelystad: PPO-AGV, (PPO publication 528).

[7] Gebremedhin, W., Endale, G. and Lemaga, B. 2008. Potato Breeding. In: Woldegiorgis G, Gebre E, Lemaga B (Eds.) Root and Tuber Crops, the Untapped Resources. Addis Ababa. Ethiopian Institute of Agricultural Research. pp. 15-32.

[8] Central Statistical Agency (CSA).2018. Agriculture Sample Survey. Central Statistical Agency. Addis Ababa.

[9] FAO. 2008. Potato world Africa: International year of the potato 2008. Food and Agriculture Ornization (FAO), Rome, Italy. http: //www.fao.org/potato-2008/en/world/africa.html

[10] Getachew, T. and A. Mela. 2000. The role of SHDI in potato seed production in Ethiopia: Experience from Alemaya integrated rural development project. Proceedings of the 5th African Potato Association Conference, Volume 5, May 29June 2, 2000, Kampala, Uganda, pp: 109-112.

[11] Sanginga, N., \& Woomer, P. 2009. Integrated soil fertility management in Africa: Principles, practices and developmental process. Nairobi: Tropical Soil Biology and Fertility Institute of the International Centre for Tropical Agriculture, TSBF-CIAT.

[12] Barry, P. B., T. S. Storey and R. Hogan. 1990. Effect of plant population and set size on yield of the main crop potato variety Cara. Irish J. Agric, Res., 29: 49-60.

[13] MoA-Ministry of Agriculture. 2010. Crop Variety Register. Plant variety release, protection and seed quality control directorate, Addis Ababa, Ethiopia.

[14] ALLEN, E. J. 1978. Plant density. In The Potato Crop: the
Scientific Basis for Improvement (ed. P. M. Harris). London: Chapman and Hall.

[15] Somanin, S. J., Mahmoodabad, R. Z, Yari Asgar. 2010. Response of agronomical, physiologically, apparent recovery nitrogen use efficiency and yield of potato tuber (Solanum tuberosum L.) to nitrogen and plant density. American Eurasian Journal Agricultural and Environmental science 9 (1): 16: 21 .

[16] Harnet Abrha, Derbew Belew and Gebremedhin Woldegiorgis. 2013. Effect of Inter- and Intra-row Spacing on Seed Tuber Yield and Yield Components of Potato at Ofla Woreda. In: Seed potato tuber production and dissemination experience challenge and prospects proceedings of the national workshop on seed potato tuber production and dissemination. 12-14 March 2012 Bahirdar, Ethiopia.

[17] Burton, W. G., 1989. The Potato. 3rd Edn., Longman Scientific and Technical Publisher, Exssex UK, pp: 72.

[18] Tesfaye G, Derbew B, Solomon T. 2013. Combined effects of plant spacing and time of earthing up on tuber quality parameters of potato (solanum tuberosum L.) at Degem district, North Showa zone of Oromia regional state. Asian Jouurnal of Crop Science 5 (1): 24-32, 41.

[19] Alemayehu T, Nigussie D, Tamado T. 2015. Response of Potato (Solanum tuberosum L.) Yield and Yield Components to Nitrogen Fertilizer and Planting Density at Haramaya, Eastern Ethiopia. Journal of Plant Sciences 3 (6): 320-328.

[20] Beukema, H. P., Van der Zaag, D. E. 1990. Introduction to Potato Production. Pudoc Wageningen, The Netherlands.

[21] Rex, B. L., Russell, W. A. 1987. The effect of spacing of seed species on yields quality and economic value for processing of Shepody potato in Manitoba. American Potato Journal 64 (4): 177-189.

[22] Zebenay D. 2015. Influence of Seed Tuber Size and Plant Spacing On Yield and Quality of Potato (Solanum Tuberosum L.) In Holeta, Central Ethiopia. MSc thesis pp. 7-13. 